\title{
Slipping Through the Cracks in Canada's Federation: A critical analysis on the situation of Non status $\underline{\text { Aboriginals }}$
}

\section{Ryan G. O'Quinn}

\section{Dalhousie University}

This is the author's first publication and he will be graduating from Dalhousie University with a Bachelor Degree double majoring in Political Science and International Development Studies this spring. Ryan has a variety of passions and interests ranging from China-Taiwan relations, development issues concerning Sri Lanka and Canadian aboriginals. He intends on completing his honors thesis in the fall time focusing on post tsunami aid distribution is Sri Lanka. With a passion for languages Ryan is bilingual in French, English and speaks basic Chinese. He will be attending ShiDa University in Taipei City to continue his development with mandarin before undertaking graduate studies. This paper was written for Professor Kristin Good and her class Dynamics of Canadian Federalism in the fall of 2006. 
The question of my identity is hard for me to understand; on one hand, when I consider myself an Indian, and I say this, the Indian says, "Who do you think you are: you are nothing but a white man.' And when I consider myself a white man, talk or act like one, the white man says to me, 'Who in the hell do you think you are? You're nothing but a damned Indian.' I am a man caught in the vacuum of two cultures with neither fully accepting me. ${ }^{1}$

-Stan Daniels, President of the Metis Association of Alberta

The population of non-status aboriginals has been estimated to be between 200,000 to two million ${ }^{2}$. Both the federal and provincial governments deny responsibility of jurisdiction over them. They have been lost and forgotten through the cracks of the Canadian federation. This is the story of non-status aboriginals in Canada. This paper will explain the significance surrounding the issue of status and how it has led to a jurisdictional stalemate between the federal government and provinces. Bill C-31

\footnotetext{
${ }^{1}$ Harold Cardinal, The Unjust Society: The Tragedy of Canada's Indians (Edmonton: M.G. Hurtig Ltd, 1969), p.20.

${ }^{2}$ Bruce Morrison, Roderick Wilson, Native Peoples: The Canadian Experience, ed. (Toronto: Oxford University Press, 2004.), p. 451.
}

will also be examined and its failure to address this issue. This paper will therefore argue that non-status aboriginals are in fact the jurisdictional responsibility of the federal government not that of the provinces and it is they who suffer the consequences.

\section{Implications of Status}

To begin, one must understand how this situation has unfolded and why an entire body of people claiming to be of aboriginal ancestry has been denied federal recognition of status. It is the inherent right of every Canadian aboriginal to have status and is the sole avenue for their recognition as a distinct culture and peoples. This gives them a specific identity and benefits in the Canadian federation unique to any other Canadian citizen. In the early 1800's when the federal government began creating reserves for Indians they had to decide who would be eligible to live there and the situation of status was born. At first, the category was broad but later was revised and limited to those who have Indian blood or if their male predecessor was Indian. ${ }^{3}$ Today the government of Canada defines a status aboriginal as follows: "The federal Indian Act defines an Indian as a person who is registered

\footnotetext{
${ }^{3}$ Donald Purich, Our land (Toronto: James Lorimer and Company), p.136.
} 
as an Indian or is entitled to be registered as an Indian." 4 This definition is vague, obscure, has led to much confusion and the beginning of the status quagmire. Only those who have been registered in the federal Indian registrar can be identified as status Indians. However, many were left out of this due process during the initial phases of assigning status; many aboriginals were either absent, ill-informed or unaware of their need to register. Federal registration was described as a quick process carried out with negligible consultation. ${ }^{5}$

\section{Enfranchisement}

Enfranchisement was another large contributor to aboriginals who no longer have or do not possess status. An aboriginal could become enfranchised in limited ways. If an aboriginal woman married a non-aboriginal man she would lose her status as an Indian. ${ }^{6}$ Therefore, she and her children became exempt from the benefits of being a recognized status Indian. Also an aboriginal would automatically become enfranchised if they "became a doctor, obtained a university degree, acquired a license to practise law or be a Notary Public or work as a minister or priest." 7

\footnotetext{
${ }^{4}$ OAHAI Manual, Government Definitions of Indian Status, October 1999, p.2.

${ }^{5}$ Morrison, Wilson, Loc. Cit., p. 37.

${ }^{6}$ Purich, Loc. Cit., p.136

${ }^{7}$ Larry Gilbert, Entitlement to Indian Status and Membership Codes in Canada (Toronto: Thompson Professional Publishing), p.24.
}

There also existed a voluntary enfranchisement clause where an aboriginal could surrender their status to obtain full rights of Canadian citizenship and acquire the right to vote and own property. ${ }^{8}$ Astoundingly, the Federal Department of Indian Affairs and Northern Development's (DIAND) original policy measured its success based on the amount of enfranchised Natives it obtained; that is, those who formally renounced Indian status and assumed all the rights, duties and obligations of citizenship in Canada! ${ }^{9}$ Nevertheless, involuntary or voluntary deprivation from status left aboriginals unable to access the rights associated with their ancestry and unrepresented in the eyes of the federation.

\section{Importance of Status}

The quest for gaining status as an aboriginal in Canada is important to aboriginals for many reasons. First, gaining status is a question of identity. Status is crucial in creating aboriginal identity and retaining their culture through reversing past policies of assimilation. As Deirdre J ordan points out "the real problem of the indigenous people is one of restructuring identity.. for many Indians that split identity (Indian and non Indian) created

\footnotetext{
${ }^{8}$ Augie Fleras, Jean Elliott, The Nations Within (Toronto: Oxford University Press), p.14.

${ }^{9}$ Ibid, p.77.
} 
confusion or guilt or lack of self confidence"10 As well, it is an issue of acceptance. The authenticity of aboriginals is often defined by where they live; a 'true' aboriginal lives on a reserve. ${ }^{11}$ Despite this measure of authenticity the majority of non-status aboriginals live in urban centers off reserves and isolated from their aboriginal communities. ${ }^{12}$

Second, non-status aboriginals are ineligible to access the rights that are granted to aboriginals of status. Larry Gilbert, in his book Entitlement to Indian Status and Membership Codes in Canada, describes the benefits of being recognized as a status aboriginal. For instance, he illustrated how status natives are able to gain funding for post secondary education, are exempt from paying premiums to a provincial health regime, can gain assistance in economic development and are exempted from federal and provincial taxes. ${ }^{13}$ These are the rights which our government has assigned for aboriginals to possess based on their unique status within our federation. Non-status aboriginals fail to qualify for these rights as long as they are not

\footnotetext{
${ }^{10}$ Diedre Jordan, Arduous Journey. ed. Rick Ponting (Toronto: Mclelland and Stewart Limited), p. 261.

${ }^{11}$ Congress of Aboriginal Peoples, Background Paper for the Canada Aboriginal Rountable Negotiations Sectoral Section, p.1.

${ }^{12}$ Congress of Aboriginal Peoples, Between Us It's a Question of Fairness (New York: New York May 24, 2005)

${ }^{13}$ Gilbert, Loc. Cit., p. 94.
}

recognized by the federal government. There are multiple justifiable reasons for the desire of non-status aboriginals to gain status in the federation; community acceptance or the federal benefits previously described by Gilbert. The most notable and controversial though is the situation of jurisdiction.

\section{Jurisdictional Quagmire: Passing the Buck}

As mentioned above, the current population of non-status aboriginals is difficult to assess. Estimates vary because of the multitude of ways one could be enfranchised as aforementioned. Nevertheless it is a significant population that has no representation and does not fall under any specific jurisdiction within our federation. The Congress of Aboriginal Peoples (C.A.P.) refers to non-status aboriginals as the "forgotten people" because in most cases both the federal and provincial governments deny jurisdiction and responsibility for these people. ${ }^{14}$

Therefore, it is necessary to examine the extent of federal or provincial government jurisdictional responsibility over non-status aboriginals. Currently the federal government is responsible for "Indians, (of status) and land

\footnotetext{
${ }^{14}$ Congress of Aboriginal Peoples, Between Us It's a Question of Fairness, Loc. Cit.
} 
reserved for Indians (native reserves.)" 15

However, as Donald Purich states, in Canadian Federalism, lines of jurisdiction are not always clear $^{16}$ and that over $50 \%$ of aboriginal people do not live on reserves in Canada. ${ }^{17}$ Therefore they would no longer be the responsibility or fall under federal jurisdiction. Yet, the provinces taking the classical view of federalism, believe that regardless of where aboriginals are living, they are the responsibility of the federal government. ${ }^{18}$

There have been responses from the federal government on this issue. In a law briefing published at the University of Alberta it was concluded that "the federal government has maintained other groups of non-status Indians, off reserve Indians and Metis living south of the $60^{\text {th }}$ parallel are within the provincial jurisdiction." 19 A report by the C.A.P. clearly states "off reserve status Indians, non-status Indians and Metis people living in urban, rural and remote communities live in a no man's land zone in terms of jurisdiction or responsibility."20 It has also been documented that DIAND's 'directional plan for the 1980's'

\footnotetext{
${ }^{15}$ Anthony Long, Governments In Conflict? (Toronto: University of Toronto Press, 1988), p. 6.

${ }^{16}$ Purich, Loc. Cit., p.68.

${ }^{17}$ Harry Daniels, Native peoples and the Constitution of Canada (Ottawa: Mutual Press, 1981), p. 20.

${ }^{18}$ Abele Prince, Aboriginal Governance in Canadian Federalism (Peterborough: Broadview Press, 2003), p. 137.

${ }^{19}$ Catherine Bell, Aboriginal Peoples and the Law (University of Alberta 1999), p.4.

${ }^{20}$ Congress Of Aboriginal People, Loc. Cit., p.2.
}

was a design for shifting responsibility for Indians to the provinces. ${ }^{21}$ This has led to conflicting allegations of responsibility surrounding off reserve aboriginals and has positioned the federal government to claim that the source of the predicament is linked to jurisdictional problems with the provinces. ${ }^{22}$

This confusion or lack of clarity has led to a large portion of aboriginal people being unrepresented and left to be balanced between both the federal government and provincial governments' claims of "passing the buck" in terms of their constitutional and jurisdictional responsibility. C.A.P concluded that:

The federal government will avoid assuming full responsibility on these matters even when historically, and to a certain point, legally, it has the primary responsibility or jurisdiction on our issues...provincial government and the latter will invoke that it is not its responsibility to address the resolution of conflicts on aboriginal rights. ${ }^{23}$

Since the Constitution Act of 1982, the federal government has now redefined its definition of aboriginals in Canada to incorporate non-status aboriginals and Metis

\footnotetext{
${ }^{21}$ Long, Loc. Cit., p.15.

${ }^{22}$ Fleras, Loc. Cit., p.18-19.

${ }^{23}$ Congress Of Aboriginal Peoples, Loc. Cit., p.2.
} 
in the constitution as native peoples. ${ }^{24}$ However, as it was stated earlier, the federal government is responsible for Indians and land reserved for Indians. Thus, there should be no debate. Non-status aboriginals are now defined in the constitution as native peoples. Under the section 91 (24) of the Constitution Act alone in conjunction with the general intentions of section 35, this would compel the assumption that the federal government is in fact responsible for the welfare of non status aboriginals. ${ }^{25}$ Conversely, this has not translated into the granting of their status, nor an improvement to address this issue.

Including non-status aboriginals in their definition has been merely rhetoric of the federal government. They are passing the buck, and it is the provinces that are under further pressure, with fewer resources, and left to suffer the consequences.

\section{Provincial Implications}

The repercussions and implications the provinces face must be analyzed. Due to urban migration from reserves, there is an expanding population of urban aboriginals who have specific needs to that of an ordinary provincial citizen. Across the entire spectrum, non-status

\footnotetext{
${ }^{24}$ Univeristy of Guelph Website, http://www.studentlife.uoguelph.ca/arc/Terminology.cfm, National Aboriginal Health Organization, 2003.

25 Paul Chartrand, ed. Who Are Canada's Aboriginal Peoples? (Saskatoon: Congress of Aboriginal Peoples, 2002.), 207.
}

aboriginals face challenges in the domain of housing, education, health, employment, identity, social problems, crime, and child welfare. ${ }^{26}$ This is a particular group that has specific needs which in turn demand responsiveness on the part of our social services provided. For example, in terms of health and social indicators, life expectancy of an aboriginal is seven years less than other Canadians, they are more likely to have hearing, sight, speech disabilities and the rate of suicide is eight times higher than the national rate for females and five times higher for males. ${ }^{27}$ Their needs and access to services provided by the government is absolutely essential to their survival and positive development in society. Alas, the federal government's refusal to acknowledge responsibility has aroused considerable concern among some provinces ${ }^{28}$ in terms of funding and resources.

This distress is reflected by the claim of the provinces that as a result of lack of funding on reserves by the federal government,

\footnotetext{
${ }^{26}$ Raymond Breton, Gail Grant, The Dynamics of Government Programs For Urban Indians in The Prairie provinces, ed. (Montreal: The Institute for Public Research Policy, 1984), p. 43-45.

27 "Backgrounder: Social Development”, Department of Indian Affairs and Northern Development, Ottawa, May $20^{\text {th }}$, 1998.

${ }^{28}$ David Hawkes, Aboriginal Peoples and Constitutional Reform (Kingston: Institute for Intergovernmental Relations, 1989), p.20.
} 
aboriginals are now seeking asylum in urban centers. This combined with the population of non-status aboriginals paints a disturbing picture for the future of the provinces. "Prairie cities such as Regina and Winnipeg are characterized by high aboriginal concentrations (about $20 \%$ of the population) Toronto alone has 65,000 urban aboriginals, making it the largest reserve in Canada." 29 This implies that non-status aboriginals who primarily reside in urban settings rely on provincial and municipal services. The provinces have voiced their concerns and claim that the federal government is offloading programs and services thereby increasing the demand on their currently strained available resources. ${ }^{30}$ This claim was solidified for the province of Saskatchewan when the federal government decided to cease payments for social assistance to aboriginals during their first year off reserve which cost over $\$ 20$ million. ${ }^{31}$

Aboriginals face greater challenges than regular citizens of the province, inflicting a greater demand on social services offered by the province and municipality. Anthony Long, in his descriptive analysis, accurately portrays this scenario:

\footnotetext{
${ }^{29}$ Fleras, Loc. Cit., p. 18.

${ }^{30}$ Hawkes, Loc. Cit., p. 18.

${ }^{31}$ Exploring the Options: Overview of the Third Round. Royal Comission on Aboriginal Peoples. (Ottawa: Public Hearings, 1993), 42.
}

Part of the pressure derives from the increasing tempo of Indian migration from reserves to urban centers...The result is that growing proportion of the Indian population is becoming a provincial responsibility by virtue of its dependence on provincial and municipal agencies for services and facilities. ${ }^{32}$

To explain this phenomenon of urban migration, the provinces continue to claim that they end up paying to solve problems caused by inadequate federal services on reserves. ${ }^{33}$ Provinces, unless given the appropriate jurisdiction of responsibility over non-status aboriginals, cannot assume sole responsibility for the further progress of their Indian citizens. They have neither the constitutional responsibility nor the financial means for the job. ${ }^{34}$ As long as the federal government denies their responsibility for non-status aboriginals, the provincial government will continue to lack the appropriate resources to respond and it is the non-status aboriginals who will carry on suffering.

The Metis and non-status aboriginals make it clear as well that they are not "citizens

\footnotetext{
${ }^{32}$ Long, Boldt, Loc. Cit., p. 10.

${ }^{33}$ Ibid, p. 10.

${ }^{34}$ Breton, Grant, Loc. Cit., p. 193.
} 
like any other"35. As Rick Ponting notes in his book Arduous J ourney, it would be inherently assimilative for one to claim them to possess equal status to that of special status which they should be eligible to claim. ${ }^{36}$ There needs to be a clear cut definitive solution to this problem. Cities, municipalities and provinces cannot adequately address the needs of these citizens as they lack extra funding. However, there has been minimal acknowledgement by the federal government despite their intervention on behalf of the non-status and Metis population. Well intentioned, yet this was done without according them special status. ${ }^{37}$

To compensate for the inadequacies of the federal government, municipal governments, local agencies in cities with large aboriginal populations have created consultative committees which work with groups and co-operative projects to address some of their issues. ${ }^{38}$ These special programs and funding have been designed and allotted to the aggrieved groups in a similar manner to that of funding for ethnic organizations through multicultural programs. Aboriginals are not aggregates of individuals; they perceive themselves to be "cultural collectives that

\footnotetext{
${ }^{35}$ Daniels, Loc. Cit., p. 20.

${ }^{36}$ Ponting, Loc. Cit., p. 237.

${ }^{37}$ Daniels, Loc. Cit., p. 20.

${ }^{38}$ Prince, Loc. Cit., p. 157.
}

deserve proper recognition. ${ }^{39}$ These preliminary efforts, however, are only a bandaid' solution unable to heal a larger systemic predicament. Moreover, the lack of federal support has not been remedied by limited federal efforts reflected in the introduction and approval of Bill C-31; the only piece of legislation that has been passed which attempts to help solve this confusing dilemma.

\section{Bill C-31: The "Abocide" Bill}

Bill C-31 was passed on the $28^{\text {th }}$ of February 1985 to amend the Indian Act so that it would fall in accordance with equality provisions of the Charter of Rights and Freedoms. ${ }^{40}$ Its primary purpose was to: remove the discriminatory practices of the Indian Act (against aboriginal women); restore status and membership rights to aboriginals who had been enfranchised; and increase control by Indian Bands over their affairs. ${ }^{41}$ There has been relative success with the passing of this Bill; enrolment in post secondary education increased as well as the number of status Indians. The increase in population of status Indians was 114,512 by December 31st 2000, with over 44,000

\footnotetext{
${ }^{39}$ Prince, Loc. Cit., p. 21.

${ }^{40}$ Megan Fury, Jill Wherrett, Indian Status and band Membership Issues (Library of Parliament Document, 2003), p.4.

${ }^{41}$ Idem.
} 
applications denied. ${ }^{42}$ Despite such successes, there are many shortcomings of Bill C-31.

\section{Bill C-31 introduced a two generational} rule, whereby a child is required to have at least two grandparents who are entitled to be registered as Indian. C.A.P has predicted that this requirement will lead to a decline in the actual status Indian population. ${ }^{43}$ The C.A.P report called “Between Us It's a Question of Fairness" has stated that by 2129 the number of children who will be eligible for status under the Indian Act will be zero due to the new regulations. ${ }^{44}$ Another report conducted by the Assembly of First Nations concluded that Bill C-31 has now created a situation where by 2010 one in five aboriginal children will no longer be eligible for status. ${ }^{45}$ Amazingly, this Bill denounced the process of enfranchisement to aboriginal women who lost status by marrying a non-aboriginal man. However, there is a new clause, section 6.1 and 6.2 .

C-31 is the gateway to a world in which some Indians are more equal than others. It establishes two 'classes' of Indians: full Indians registered under 6.1 and half Indians under 6.2. These classes have unequal

\footnotetext{
${ }^{42}$ Megan Fury, Jill Wherrett, Loc. Cit., p.5.

${ }^{43}$ Michelle Mann. Indian Registration: Unrecognized and Unstated Paternity (Ottawa Policy Research Fund, 2005), p. 5.

${ }^{44}$ Congress of Aboriginal Peoples, Between Us It's a Question of Fairness. Loc. Cit., p. 2.

${ }^{45}$ Assembly of First Nations
}

rights: they differ in their ability to pass Indian Status to children. ${ }^{46}$

This second-generation cut-off rule therefore means that there would be a loss of status after two successive generations of parenting by non-Indians.

Paradoxically, Bill C-31 has increased the population of urban aboriginals and has further complicated the jurisdictional problem concerning them. Such confusion has occurred as the population of off-reserve status aboriginals residing in urban centers doubled between 1981 and 1991. ${ }^{47}$ Subsequently, due to the increase of pressure on cities because of urban migration, further provincial and municipal resources will need to be allocated despite the lack of currently existing financial revenues. The federal government provides per capita \$7, 439 for aboriginals living on reserve as compared to $\$ 539.48$ The disparity and inequality of payments in combination of urban migration resonate loud and clear. Such demands must force the federal and provincial governments to acknowledge and address these demographic changes to urban centers.

\footnotetext{
${ }^{46}$ Mann, Loc. Cit., p. 3.

${ }^{47}$ Fury, Wherrett, Loc. Cit., p. 7.

${ }^{48}$ Exploring the Options: Overview of the Third Round. Royal Commission on Aboriginal Peoples. (Ottawa: Public Hearings, 1993), 44.
} 
There have been exchanges of opinion surrounding the allotment of status; aboriginals declare that the federal government has no right to decide who is or is not eligible for status. ${ }^{49}$ On the other hand, the federal government claims that they have an opinion in the matter due to the considerable federal expenditure involved. 50 The Assembly of First Nations stated their position: "After living with Bill C-31 for 20 years we can clearly and unequivocally say that it has failed Canada and it has failed First Nations...control over status is still held by the crown." 51

\section{Democratic Deficit}

When the federal government sneezes, it is the provinces that catch the cold. We are witnessing a dramatic democratic deficit in our federation. The first inhabitants of our country exist without representation and are being denied proper effective federal assistance. Nonstatus aboriginals have no order of government to address their needs or give them representation. The provinces are forced to make do with minimal funding for social programs to respond to a situation which is no longer a mere debate over jurisdictional responsibility; it is a humanitarian crisis and disaster in the making. Twice last week on

\footnotetext{
${ }^{49}$ Purich, Loc. Cit., p. 137

${ }^{50}$ Idem.

${ }^{51}$ Assembly of First Nations, Bill C-31 Twenty Years Later (June 28 $\left.{ }^{\text {th }}, 2005\right)$ p. 1.
}

November $21^{\text {st }}$ and $24^{\text {th }}$, aboriginals made headlines on the CBC news. The first claimed aboriginal children in Canada are the poorest in the country and the second stated that the goals of the Royal Commission on Aboriginals Peoples have not been met and that funding shortages are increasing the gap in the quality of life for aboriginals compared to that of nonnative Canadian citizens. ${ }^{52}$ Their issues are nothing of the past, they are happening today in our communities, cities and on federal reserves. Co-operation among all levels of the Canadian government is necessary to effectively address this issue. Our federation is fragmented and this has left thousands without a voice.

\section{Conclusion}

There is no credible reason why such a large population of aboriginals continues to be denied recognition of their aboriginal status. The federal government must come to terms with its jurisdictional responsibility over nonstatus aboriginals. Moreover, the federal

\footnotetext{
${ }^{52}$ (November 21 ${ }^{\text {st }}$, 2006). Aboriginal Peoples, 10 Years After Royal Commission.Canada Broadcasting Corporation. Retrieved November $21^{\text {st }}$, 2006, from www.cbc.ca/news/background/aboriginals/statusreport2006.html and

(November $24^{\text {th }}$, 2006). Aboriginal Children are Poorest in Country: Report. Canada Broadcasting Corporation. Retrieved November $24^{\text {th }}$, 2006, from www.cbc.ca/canada/montreal/story/2006/11/24/childpoverty.html
} 
government must cease adding additional pressure to the provinces, cities and municipal governments as they continue to deny adequate financial support. In addition, many aboriginals have been denied their status through enfranchisement and they lack the ability to regain it through the discriminatory practices of Bill C-31. Such non-status aboriginals do not possess the proper resources within an urban setting due to this jurisdictional conflict between the federal government and the provinces. Who is passing the buck? It's obvious and must be further emphasized in our legislatures and our policies. This democratic deficit is denying non-status aboriginals their inherent right to equality and specialized treatment in the federation.

Provincial and municipal governments are suffering as well; their resources are stretched and exhausted. These inadequacies and Bill C31 may result in the assimilation of an entire group of people and uncovers the Canadian legacy of ignoring the rights of aboriginal groups; the threat of assimilation mirrors the original objective of the Indian Act - to subsume aboriginal peoples. 


\section{Bibliography}

Abele, J ., Prince, M. (2003) Aboriginal Governance and Canadian Federalism: A To-Do List for Canada. In Francois Rocher and Miriam Smith.Eds. New Trends in Canada Federalism (second edition). Peterborough, Broadview Press.

Breton, R., Grant, G., (Ed.). (1984). The Dynamics of Government Programs for Urban Indians in The Prairie Provinces. Montreal: The Institute for Research on Public Policy.

Cardinal, H. (1969).The Unjust Society: The Tragedy of Canada's Indians. Edmonton: M.G. Hurtig LTD.

Chartrand, Paul. Ed. (2002) Who Are Canada's Aboriginal Peoples? Recognition, Definition and J urisdiction. Saskatoon: Purich Publishing Ltd.

Daniels, H., (1981). Native People and the Constitution of Canada: The Report of the Metis and Non-Status Indian Constitutional Review Commission. Ottawa: Mutual Press.

Fleras, A., Elliott, J ., (1992). Relations in Canada, the United States, and New Zealand. Toronto: Oxford University Press.

Gilbert, L. (1996). Entitlement to Indian Status and Membership Codes in Canada. Toronto: Thompson Professional Publishing.

Hawkes, D. (1989). Aboriginal People and Constitutional Reform: What Have We Learned? Kingston: Institute of Governmental Relations.

Indian and Northern Affairs Canada. (May 20th 1998.) Backgrounder: Social Development. Ottawa: Department of Indian Affairs and Northern Development.

Long, Anthony J .(Ed.). (1988). Governments in Conflict? Provinces and Indian Nations in Canada. Toronto: University of Toronto Press.

Mann, M., (2005). Indian Registration: Unrecognized and Unstated Paternity. Ottawa: Policy Research Fund.

Morrison, B., Wilson, C., (Ed.). (2004). Native Peoples: The Canadian Experience. Toronto: Oxford University Press.

Ponting, R. (Ed.). (1986). Arduous J ourney: Canadian Indians and Decolonization. Toronto: McClelland and Stewart Limited.

Purich, D. (1986). Our Land: Native Rights in Canada. Toronto: J ames Lorimer \& Company.

Royal Commission on Aboriginal Peoples. (1993). Exploring the Options: Overview of the Third Round. (Ottawa: Minister of Supply and Services Canada). 
(October 1999). Government Definitions of Indian Status: OAHAI Manual. Retrieved November $4^{\text {th }}$, 2006, from http:/ / www.ofifc.org/ oahai/ Acrobatfiles/ Govdef.pdf

(J anuary 7th, 2003). Background Paper for the Canada Aboriginal Roundtable Negotiations Sectoral Session. Congress of Aboriginal People. Retrieved November 10th, 2006, from http:// www.abopeoples.org/RoundTable/ Backgrounders/NegotiationsBkgnd.pdf

(May 21st, 2005). Between Us It's a Question of Fairness. Congress of Aboriginal People. Retrieved November 10th, 2006, from http:// www.abo-peoples.org/Communications/Events/ UN\%20PFII\%20\%202005.pdf

(J une 28th 2005). Bill C-31 Twenty Years Later. Assembly of First Nations. Retrieved November $4^{\text {th }}$, 2006, from http:// afn.ca/ article.asp?id=1548

(November 21st, 2006). Aboriginal Peoples, 10 Years After Royal Commission. Canada Broadcasting Corporation. Retrieved November 21st, 2006, from www.cbc.ca/ news/ background/aboriginals/status-report2006.html and

(November 24th 2006 ). Aboriginal Children are poorest in Country: Report. Canada Broadcasting Corporation. Retrieved November $24^{\text {th }}, 2006$, from www.cbc.ca/ canada/ montreal/ story/2006/11/24/ child-poverty.html

Catherine Bell, Aboriginal Peoples and the Law. University of Alberta. Retrieved November $10^{\text {th }}$, 2006, from http:// www.law.ualberta.ca/Current-Students/Resources/Course-Notes/CatherineBell/aboriginal/lp02.php

Megan Fury, Jill Wherrett, (February 2003). Indian Status and band Membership Issues (Library of Parliament Document,2003), Retrieved November 1st, 2006 from http:// www.parl.gc.ca/ information/library/ PRBpubs/ bp410-e.htm 